\title{
Effect of Different Potassium Rates and Hybrid Maize Varieties on the Grain Yield Under Field Condition at South Sulawesi, Indonesia
}

\author{
M Akil*, F Tabri, Syafruddin and M Azrai \\ South Sulawesi, Indonesia
}

*Corresponding author: M Akil, Jl Dr Ratulangi No. 274 Maros, 90514, South Sulawesi, Indonesia.

Received Date: October 08, 2018

Published Date: November 08, 2018

\begin{abstract}
Potassium (K) is an essential nutrient for plant health and play critical roles in controlling protein metabolism, enzyme activity and various metabolic processes. In order to investigate the effect of different potassium rates and hybrid maize varieties on the yield and yield components of maize, an experiment was carried out at the Bajeng Experimental Station, Indonesian Cereals Research Institute, Gowa, South Sulawesi, from May to September 2017. The level of K on site of the experiment is $0.26 \mathrm{mg} \mathrm{kg}^{-1}$. The potential grain yield of three hybrid maize varieties has different. Nasa-29 has potential grain yield (13.5 $\left.\mathrm{t} \mathrm{ha}^{-1}\right)$, Bima-20 (12.8 $\left.\mathrm{t} \mathrm{ha}{ }^{-1}\right)$ and Bima-4 (11.7 $\left.\mathrm{t} \mathrm{ha}^{-1}\right)$. The experiment was laid out in randomized split plot design with three replications having a plot size of $9 \mathrm{~m} \mathrm{x}$ $6 \mathrm{~m}$ with planting density $75 \times 25 \mathrm{~cm}$. The main plot was provided with six different levels of potassium i.e. $0,20,40,60,80$ and 100 $\mathrm{kg}$ K2O ha-1. The sub plot consisted of three hybrid maize varieties i.e. Nasa-29, Bima-20 and Bima-4. The interaction of different levels of potassium and hybrid maize varieties significantly affected to maize cob diameter, weight of 1000 grains, and grain yield. The application of potassium at the rate of $60 \mathrm{~kg} \mathrm{~K}_{2} \mathrm{O} \mathrm{ha}^{-1}$ for Nasa-29 variety produced the highest grain yield $\left(11.33 \mathrm{ha}^{-1}\right)$ under field condition at the agro-ecological of Gowa, South Sulawesi.
\end{abstract}

Keywords: Grain yield; Hybrid maize; Potassium level; South sulawesi

\section{Introduction}

The potential grain yield of different hybrid maize varieties has different. Nasa-29 variety has potential grain yield (13.5 t ha-1), Bima-20 (12.8 $\left.\mathrm{t} \mathrm{ha}^{-1}\right)$ and Bima-4 (11.7 $\left.\mathrm{t} \mathrm{ha}^{-1}\right)$. These varieties have resistance to downy mildew, rust and leaf blight [1]. Hybrid maize has a potential high yielding, therefore require an adequate supply of potassium $(\mathrm{K})$ after nitrogen $(\mathrm{N})$ and phosphorus $(\mathrm{P})$ to meet production potential. The $\mathrm{K}$ uptake pattern of maize is distinctive in that $\mathrm{K}$ is taken up rapidly and early in the crop's growth cycle, with some crops accumulating more than $5 \mathrm{~kg} \mathrm{~K} \mathrm{ha}^{-1}$ daily during the period between 4 to 7 weeks after planting [2].

Potassium is an essential nutrient that is crucial for healthy plant growth and is classified as a macronutrient due to large quantities of $\mathrm{K}$ being taken up by plants during their life cycle. Potassium availability, however, is often limited in agricultural fields and thus crop yields and quality are reduced. Therefore, improving the efficiency of potassium uptake and transport, as well as its utilization, in plants is important for agricultural sustainability [3]. Soils can supply some K for crop production, but when the supply from the soil is not adequate, $\mathrm{K}$ must be supplied in a fertilizer program. Potassium is necessary for plant health and it constitutes up to $10 \%$ of plant dry weight $[4,5]$.

Potassium plays critical roles in controlling ion homeostasis, osmoregulation, protein metabolism, enzyme activity, membrane polarization, and various metabolic processes [6,7]. Additionally, fundamental physiological processes in plants, including photosynthesis, photorespiration, and growths are dramatically affected by $\mathrm{K}+$ availability $[8,9]$.

According to Shin [3], there are four strategies for improving potassium use efficiency in plants are proposed; 1) increased root volume, 2) increasing efficiency of potassium uptake from the soil and translocation in plant 3) increasing mobility of potassium in soil, and 4) molecular breeding new varieties with greater potassium efficiency through marker assisted selection which will require identification and utilization of potassium associated quantitative trait loci. 
Several factors impact on the ability of a soil to meet the $\mathrm{K}$ demands of a growing maize crop, including: (1) The soil solution $\mathrm{K}$ concentration, (2) The capacity of the soil to buffer the soil solution K concentration (3) Soil moisture content (4) Soil texture and structure, and (5) The distribution of soil K reserves [10].

Potassium is taken up in large quantities by plants, is highly mobile within plant vascular systems and plays an essential role in a number of metabolic functions. Over 60 enzymes require $\mathrm{K}$ for catalytic activity, some of which play a role in protein synthesis and sugar degradation. Water relations of plant cells rely on the rapid movement of $\mathrm{K}$ ions in order to maintain and regulate turgidity and stomata control can be affected if $\mathrm{K}$ is deficient. The detrimental effect on stomata regulation can result in reduced photosynthetic capacity. Potassium also promotes the translocation of photosynthetic assimilates from leaves to grain through the phloem. Reduced stress resistance in plants has also been attributed to $\mathrm{K}$ deficiency. Pest and disease resistance can be improved by $\mathrm{K}$ application through several mechanisms including by: (1) Altering the metabolic compatibility of a host plant for the pest or pathogen,

(2) Enhancing the accumulation of inhibitory chemicals in the plant

(3) Hastening plant wound healing, (4) Improving the structural integrity of plant tissues, and (5) Stimulating healthy growth to avoid infection. Potassium fertilization has been shown to decrease the impact of several diseases of maize including boil smut, leaf blight and stalk rot.

Potassium is associated with movement of water, nutrients, and carbohydrates in plant tissue. Potassium is involved with enzyme activation within the plant which affects protein, starch and adenosine tri phosphate (ATP) production. The production of ATP can regulate the rate of photosynthesis. Potassium also helps to regulate the opening and closing of the stomata which regulates the exchange of water vapor, oxygen, and carbon dioxide $[4,7,11$ 15]. If $\mathrm{K}$ is deficient or not supplied in adequate amounts, growth is stunted, and yield is reduced. Other roles of $\mathrm{K}$ include, increased root growth and improves drought resistance, maintains turgor, reduces water loss and wilting, aids in photosynthesis and food formation, reduces respiration, preventing energy losses, enhances translocation of sugars and starch, produces grain rich in starch, increases protein content of plants, builds cellulose and reduces lodging, and helps retard crop diseases.

\section{Materials and Methods}

The experiment was conducted at the Bajeng Experimental Station, Indonesian Cereals Research Institute, Gowa, South Sulawesi, from May to September 2017. The level of K on site of the experiment is 0.26 me100 g-1. The experiment was laid out in randomized split plot design with three replications. The main plot was provided with six levels of potassium i.e. 0, 20, 40, 60, 80 and $100 \mathrm{~kg} \mathrm{~K}_{2} \mathrm{O} \mathrm{ha}{ }^{-1}$. The sub plot consisted of three hybrid maize varieties i.e. Nasa-29, Bima-20 and Bima-4.

The land was prepared with gramoxon herbicide sprayed a rate of $4 \mathrm{l} \mathrm{ha} \mathrm{a}^{-1}$. The size of the plot is $9 \mathrm{~m} \times 6 \mathrm{~m}$ with planting density 75 $\mathrm{cm} \times 25 \mathrm{~cm}$. Before sowing, seeds were mixed with saromil fungicide to prevent downy mildew disease a rate of $2.5 \mathrm{~g} \mathrm{~kg}^{-1}$ seed. Pests were controlled with furadan $3 \mathrm{G}$, which is applied at the planting time in the hole of the seeds and 15 days after planting (dap), applied in the tops of the leaves of plants at $5 \mathrm{~kg} \mathrm{ha}^{1}$, respectively. Irrigation was given at 10 days interval during crop growth. Irrigation was stopped two weeks prior to harvest of the crop.

Fertilizers at rate of $210 \mathrm{~kg} \mathrm{~N}^{-1}$ and $100 \mathrm{~kg} \mathrm{P}_{2} \mathrm{O}_{5}$ ha $^{-1}$ were applied. One-half of the nitrogen (source from urea) and potassium (source from $\mathrm{KCl}$ ) and all phosphorus (source from SP 36) were applied at 7 dap. The remaining of $\mathrm{N}$ and $\mathrm{K}$ were applied at 37 dap.

Soil sample from location site was analyzed at soil laboratory, Maros. Soil sample for analysis was taken before starting the research to analysis of soil texture, $\mathrm{pH}$, organic $\mathrm{C}$, total of $\mathrm{N}$ content, available $\mathrm{P}$, and available K. Data were collected includes: plant height $(\mathrm{cm})$ and ear height $(\mathrm{cm})$ at 75 dap, cob diameter, 1000 grain-weight $(\mathrm{g})$ and grain yield $\left(\mathrm{t} \mathrm{ha}^{-1}\right)$ at $15 \%$ moisture content. Data were analyzed using standard Analysis of Variance (ANOVA) technique and means were compared using Duncan's Multiple Range Test (DMRT) at 5\% level [16].

\section{Results and discussions}

\section{Soil properties}

Based on Land Resource Atlas of Exploration Indonesia made by Indonesian Center for Soil and Agroclimate Research (2000), the order of soil in Bajeng, Gowa, is Inceptisol. It is very potential for agricultural food crops such as maize [17-21]. Result of the physical analysis of soil indicates that the soil texture is silt loam. The chemical analysis indicates that the $\mathrm{pH}$ is 6,3 which is moderately acid. The organic matter content is $1.93 \%$ (low) and the total nitrogen content is 0.13 (low). The available phosphorus is $70 \mathrm{mg} \mathrm{kg}^{-1}$ (very high). Its available potassium is $0.26 \mathrm{mg} \mathrm{kg}^{-1}$ (low), available calcium is $13.72 \mathrm{mg} \mathrm{kg}^{-1}$ (high) and available $\mathrm{Mg}$ is 3.57 (high) (Table 1).

Table 1: Some physical and chemical properties of soil in the experimental site.

\begin{tabular}{|c|c|c|}
\hline Properties & Value & Remarks \\
\hline Physical & & \\
\hline Clay (\%) & 10 & \\
\hline Silt (\%) & 53 & \\
\hline Sand (\%) & 37 & \\
\hline Texture class & Loam & Medium texture \\
\hline Soil Order & & Inceptisol \\
\hline Chemical & & \\
\hline pH H2O (1: 2.5$)$ & 6.29 & Moderately acid \\
\hline C- Organic (\%) & 1.93 & Low \\
\hline N-Total (\%) & 0.13 & Low \\
\hline P-Bray I $\left(\mathrm{mg} \mathrm{kg}^{-1}\right)$ & 70 & Very low \\
\hline K (mg kg-1) & 0.26 & Normal \\
\hline Ca $\left(\mathrm{mg} \mathrm{kg}^{-1}\right)$ & 13.72 & High \\
\hline Mg $\left(\mathrm{mg} \mathrm{kg}^{-1}\right)$ & 3.57 & Very high \\
\hline
\end{tabular}

\section{Plant height}

The analysis of variance on the plant height at 75 dap revealed that maize potassium level, maize varieties and their interaction were significant. The average plant heights at 75 dap ranged from $186.7 \mathrm{~cm}$ to $210.9 \mathrm{~cm}$ (Table 2). Data in Table 2 further showed that the average mean Nasa-29 $(203.1 \mathrm{~cm})$ was taller than Bima-4 $(198.4 \mathrm{~cm})$ and Bima-20 (194.1cm). 
Table 2: Plant height $(\mathrm{cm})$ at 75 dap of three varieties in different potassium rates. Gowa, South Sulawesi. 2017.

\begin{tabular}{|c|c|c|c|c|}
\hline \multirow{2}{*}{ Potassium Rates $\left(\mathbf{k g ~ K}_{\mathbf{2}} \mathbf{O}\right.$ ha $\left.^{-1}\right)$} & \multicolumn{2}{|c|}{ VARIETIES } & \multirow{2}{*}{ BIMA-4 } \\
\cline { 2 - 5 } & NASA-29 & BIMA-20 & $197.6 \mathrm{ab}$ & $190.5 \mathrm{~b}$ \\
\hline 0 & $187.2 \mathrm{~b}$ & $186.7 \mathrm{~b}$ & $201.2 \mathrm{ab}$ & $200.5 \mathrm{ab}$ \\
\hline 20 & $205.8 \mathrm{ab}$ & $194.4 \mathrm{ab}$ & $192.1 \mathrm{ab}$ & $198.0 \mathrm{ab}$ \\
\hline 40 & $203.1 \mathrm{ab}$ & $198.8 \mathrm{ab}$ & $199.2 \mathrm{ab}$ & $196.9 \mathrm{ab}$ \\
\hline 60 & $201.9 \mathrm{ab}$ & $189.5 \mathrm{~b}$ & $198.8 \mathrm{ab}$ & $201.7 \mathrm{ab}$ \\
\hline 80 & $210.9 \mathrm{a}$ & $195.5 \mathrm{ab}$ & $201.2 \mathrm{ab}$ & $203.6 \mathrm{a}$ \\
\hline 100 & $209.7 \mathrm{a}$ & $199.9 \mathrm{ab}$ & 198.4 & 198.5 \\
\hline
\end{tabular}

$\mathrm{CV}(\mathrm{a})=7.3 \%$

$\mathrm{CV}(\mathrm{b})=3.7 \%$

Means in a column followed by a common letter are not significantly different at the $5 \%$ level by DMRT.

Potassium at rate $80 \mathrm{~kg} \mathrm{~K}_{2} \mathrm{O} \mathrm{ha}^{-1}$ for Nasa-29 had the tallest plants among all other potassium rate and maize varieties $(210.9 \mathrm{~cm})$. The interaction effects showed that Nasa-29 applied with $80 \mathrm{~kg} \mathrm{~K}_{2} \mathrm{O}$ $\mathrm{ha}^{-1}$ was the tallest plant. This finding showed that in term of plant height at 75 dap, Nasa-29 was responses to potassium fertilizer, but Bima-20 and Bima-4 were not responses to potassium application. These plant height differences among the varieties in relation to the potassium fertilizer were attributed to genetic variability. Plant height strongly influenced by environmental condition during stem elongation as expected.

\section{Cob diameter}

The cob diameter revealed that the hybrid maize varieties different significantly. Bima-4 significantly produced the highest cob diameter $(5.11 \mathrm{~cm})$, but Nasa-29 produced the lowest cob diameter $(4.74 \mathrm{~cm})$ (Table 3$)$.

Table 3: Cob diameter $(\mathrm{cm})$ at 75 dap of three varieties in different potassium rates. Gowa, South Sulawesi. 2017.

\begin{tabular}{|c|c|c|c|c|}
\hline \multirow{2}{*}{ Potassium Rates $\left(\mathbf{k g ~ K}_{\mathbf{2}} \mathbf{O} \mathbf{~ h a}^{-1}\right)$} & \multicolumn{3}{|c|}{ VARIETIES } & \multirow{2}{*}{ P0TASSIUM-MEAN } \\
\cline { 2 - 5 } & NASA-29 & BIMA-20 & BIMA-4 & $4.89 \mathrm{~b}$ \\
\hline 0 & $4.71 \mathrm{~h}$ & $4.94 \mathrm{defg}$ & $5.01 \mathrm{bcde}$ & $5.01 \mathrm{a}$ \\
\hline 20 & $4.74 \mathrm{gh}$ & $5.09 \mathrm{abcde}$ & $5.21 \mathrm{ab}$ & $4.95 \mathrm{ab}$ \\
\hline 40 & $4.79 \mathrm{fgh}$ & $4.89 \mathrm{efgh}$ & $5.17 \mathrm{abc}$ & $4.96 \mathrm{ab}$ \\
\hline 60 & $4.79 \mathrm{fgh}$ & $5.13 \mathrm{abcd}$ & $4.97 \mathrm{cdef}$ & $4.89 \mathrm{~b}$ \\
\hline 80 & $4.71 \mathrm{~h}$ & $4.89 \mathrm{efgh}$ & $5.07 \mathrm{abcde}$ & $5.03 \mathrm{a}$ \\
\hline VARIETIES-MEAN & $4.69 \mathrm{~h}$ & $5.17 \mathrm{abc}$ & $5.24 \mathrm{a}$ & 4.96 \\
\hline
\end{tabular}

Means in a column followed by a common letter are not significantly different at the $5 \%$ level by DMRT

$\mathrm{CV}(\mathrm{a})=7.9 \%$

$\mathrm{CV}(\mathrm{b})=6.6 \%$

The cob diameter for Nasa-29 was not significantly different among potassium rate. The highest cob diameter $(5.24 \mathrm{~cm})$ produced by Bima- 4 at applied $100 \mathrm{~kg} \mathrm{~K}_{2} \mathrm{O} \mathrm{ha}^{-1}$. These cob diameter

differences among the varieties in relation to the potassium fertilizer were attributed to genetic variability.

\section{0 grains weight}

Table 4: 1000-grains weight (g) of three varieties at different potassium rates. Gowa, South Sulawesi. 2017.

\begin{tabular}{|c|c|c|c|c|}
\hline \multirow{2}{*}{ Potassium Rates $\left(\mathbf{k g ~ K}_{\mathbf{2}} \mathbf{O ~ h a}^{-1}\right)$} & \multicolumn{3}{|c|}{ VARIETIES } & \multirow{2}{*}{ P0TASSIUM-MEAN } \\
\cline { 2 - 5 } & NASA-29 & BIMA-20 & $338.5 \mathrm{bc}$ & 328.2 \\
\hline 0 & $325.9 \mathrm{bcd}$ & $320.1 \mathrm{~d}$ & $344.5 \mathrm{ab}$ & 337.3 \\
\hline 20 & $346.5 \mathrm{ab}$ & $320.8 \mathrm{~cd}$ & $352.6 \mathrm{ab}$ & 346.8 \\
\hline 40 & $360.9 \mathrm{ab}$ & $326.9 \mathrm{~cd}$ & $366.0 \mathrm{ab}$ & 351.4 \\
\hline 60 & $361.0 \mathrm{ab}$ & $327.2 \mathrm{bcd}$ & $368.4 \mathrm{a}$ & 344.1 \\
\hline 80 & $345.3 \mathrm{ab}$ & $318.6 \mathrm{bcd}$ & $336.6 \mathrm{ab}$ & 336 \\
\hline 100 & $345.1 \mathrm{ab}$ & $326.2 \mathrm{~cd}$ & $351.1 \mathrm{a}$ & 340.6 \\
\hline
\end{tabular}

Means in a column followed by a common letter are not significantly different at the $5 \%$ level by DMRT

$\mathrm{CV}(\mathrm{a})=9.7 \%$

$\mathrm{CV}(\mathrm{b})=5.6 \%$ 
Potassium level, maize varieties and their interaction significantly influence 1000 grains weight (Table 4). The heavier mean of the weight 1000 grains was Bima-4 (351.1g followed by Nasa-29 (347.5g) and Bima-20 323.3g). The insignificant potassium rate values indicated that all potassium rates were comparable in term of weight 1000 grains. According to Yoshida (1981), grain weight is a stable varietal characteristic. The differences could be due to genetic variability in nature.

\section{Grain yield:}

Table 5: Grain yield (t ha-1) of three varieties at different potassium rates. Gowa, South Sulawesi. 2017.

\begin{tabular}{|c|c|c|c|c|}
\hline \multirow{2}{*}{ Potassium Rates $\left(\mathbf{k g ~ K}_{\mathbf{2}} \mathbf{O ~ h a ~}^{-1}\right)$} & \multicolumn{3}{|c|}{ VARIETIES } & \multirow{2}{*}{ P0TASSIUM-MEAN } \\
\cline { 2 - 5 } & NASA-29 & BIMA-20 & $9.48 \mathrm{cdef}$ & $9.63 \mathrm{~b}$ \\
\hline 0 & $10.54 \mathrm{abcd}$ & $8.87 \mathrm{ef}$ & $9.71 \mathrm{~b}$ \\
\hline 20 & $11.15 \mathrm{ab}$ & $8.40 \mathrm{f}$ & $9.59 \mathrm{bcdef}$ & $10.21 \mathrm{a}$ \\
\hline 60 & $11.02 \mathrm{abc}$ & $9.41 \mathrm{cdef}$ & $10.19 \mathrm{abcde}$ & $10.14 \mathrm{ab}$ \\
\hline 80 & $11.33 \mathrm{a}$ & $9.26 \mathrm{def}$ & $10.04 \mathrm{abcde}$ & $9.63 \mathrm{~b}$ \\
\hline 100 & $10.22 \mathrm{abcde}$ & $9.49 \mathrm{cdef}$ & $10.04 \mathrm{abcde}$ & $9.58 \mathrm{~b}$ \\
\hline VARIETIES-MEAN & $10.08 \mathrm{abcde}$ & $9.12 \mathrm{ef}$ & $9.54 \mathrm{cdef}$ & $9.81 \mathrm{~b}$ \\
\hline
\end{tabular}

Means in a column followed by a common letter are not significantly different at the $5 \%$ level by DMRT

$\mathrm{CV}(\mathrm{a})=8.7 \%$

$\mathrm{CV}(\mathrm{b})=7.5 \%$

Potassium level, maize varieties and their interaction significantly influenced grain yield. The higher mean of the grain yield was Nasa-29 (10.72t ha-1) significantly different with Bima-4 (9.8t ha-1) and Bima-20 (9.09t ha-1) (Table 5).

The significant potassium rate means for grain yield indicated that the application of potassium at $60 \mathrm{~kg} \mathrm{~K}_{2} \mathrm{O} \mathrm{ha}{ }^{-1}$ for Nasa-29 showed that the highest grain yield $\left(11.33 \mathrm{t} \mathrm{ha}^{-1}\right)$.

\section{Conclusion}

The interaction of different rates of potassium and hybrid maize varieties significantly affected to maize cob diameter, weight of 1000 grains, and grain yield. The application of potassium at the rate of $60 \mathrm{~kg} \mathrm{~K}_{2} \mathrm{O} \mathrm{ha}^{-1}$ for Nasa-29 variety produced the highest grain yield (11.33 ha-1) under field condition at the agro-ecological of Gowa, South Sulawesi.

\section{Acknowledgement}

We are thankful to the technician, Mr Rahman for the excellent helps and assistance in the field and Ms Murniati for statistical analysis.

\section{Conflict of Interest}

No Conflict of Interest.

\section{References}

1. Aqil E, Arvan YR (2014) Description of maize varieties. Indonesian Cereals Research Institute. Indonesian Agency of Agricultural Research and Development. Maros, South Sulawesi. Indonesia, pp. 45.

2. White JR (2002) Potassium distribution in Ferrosols and its influence on rain-fed crop production in the South Burnett region of Queensland. $\mathrm{PhD}$, University of Queensland, St Lucia pp. 1-17.

3. Shin R (2014) Strategies for improving potassium use efficiency in plant. Mini Review. Mol Cell 37(8): 575-584.

4. Adams E, Shin R (2014) Transport, signaling, and homeostasis of potassium and sodium in plants. J Integr Plant Biol 56(3): 231-249.

5. Walker DJ, Leigh RA, Miller AJ (1996) Potassium homeostasis in vacuolate plant cells. Proc Natl Acad Sci USA 93(19): 10510-10514.

6. Amtmann A, Hammond JP, Armengaud P, White PJ (2005) Nutrient sensing and signaling in plants: Potassium and phosphorus. Adv Bot Res 43: 209-257.

7. Schachtman DP, Shin R (2007) Nutrient sensing and signaling: NPKS. Annu Rev Plant Biol 58: 47-69.

8. Gattward JN, Almeida AA, Souza JO, Gomes FP, Kronzucker HJ (2012) Sodium-potassium synergism in Theobroma cacao: stimulation of photosynthesis, water-use efficiency and mineral nutrition. Physiol Plant 146(3): 350-362.

9. Pettogrew WT (2008) Potassium influences on yield and quality production for maize, wheat, soybean and cotton. Physiol Plant 133(4): 670-681.

10. White JR (2003) Potassium nutrition in Australian high-yielding maize production systems - a review. Paper presented at the 5th Australian Maize Conference, 18-20th February 2003, Toowoomba, Queensland, Australia.

11. Amtmann A, Blatt MR (2009) Regulation of macronutrient transport. New Phytol 181(1): 35-52.

12. Gierth M, Maser P, Schroeder JI (2005) The potassium transporter AtHAK5 functions in $\mathrm{K}^{+}$deprivation-induced high affinity $\mathrm{K}+$ uptake and AKT1 $\mathrm{K}^{+}$channel contribution to $\mathrm{K}+$ uptake kinetics in Arabidopsis roots. Plant Physiol 137(3): 1105-1114.

13. Grabov A (2007) Plant KT/KUP/HAK potassium transporters: single family - multiple functions. Ann Bot 99(6): 1035-1041.

14. Voelker C, Schmidt D, Mueller Roeber B, Czempinski K (2006) Members of the Arabidopsis AtTPK/KCO family form homomeric vacuolar channels in planta. Plant J 48(2): 296-306.

15. Wang M, Zheng Q, Shen Q Guo S (2013) The critical role of potassium in plant stress response. Int J Mol Sci 14(4): 7370-7390.

16. Gomez KA, AA Gomez (1984) Statistical Procedures for Agricultural Research. Second Edition. A. International Rice Research Institute Book. A Wiley Interscience Publication. Printed in Singapore, pp. 1-690.

17. Subagyo H, N Suharta, AB Siswanto (2000) Land Agricultural in Indonesia In Land Resources Management. Indonesian Center for Soil and Agroclimate Research, Indonesia, pp. 21-65.

18. Fu HH, Luan S (1998) AtKuP1: a dual-affinity $\mathrm{K}^{+}$transporter from Arabidopsis. Plant Cell 10(1): 63-73.

19. Indonesian Center for Soil and Agro climate Research. 2000. Exploration of Land Resource. Atlas of Indonesia. Scale 1:1.000.000. Indonesian 
Agency for Agricultural Research and Development. Department Agriculture of Indonesia.

20. Suelter CH (1985) Role of potassium in enzyme catalysis. In "Potassium in Agriculture" (RD Munson edn), Madison.
21. Yoshida S (1981) Fundamentals of rice crops science. International Rice Research Institute (IRRI). Los Banos. Laguna Philippines, pp. 269. 